\title{
A Regional Scale Investigation on Groundwater Arsenic in Different Types of Aquifers in the Pearl River Delta, China
}

\author{
Qinxuan Hou, ${ }^{1}$ Jichao Sun, ${ }^{1}$ Jihong Jing, ${ }^{1}$ Chunyan Liu, ${ }^{1}$ Ying Zhang, \\ Jingtao Liu $\mathbb{D}^{1}{ }^{1}$ and Mengjian Hua ${ }^{2}$ \\ ${ }^{1}$ Institute of Hydrogeology and Environmental Geology, Chinese Academy of Geological Sciences, Shijiazhuang, China \\ ${ }^{2}$ Tsinghua University High School, Beijing, China
}

Correspondence should be addressed to Jingtao Liu; 728881944@qq.com

Received 10 October 2017; Revised 4 December 2017; Accepted 14 January 2018; Published 18 February 2018

Academic Editor: Meijing Zhang

Copyright (C) 2018 Qinxuan Hou et al. This is an open access article distributed under the Creative Commons Attribution License, which permits unrestricted use, distribution, and reproduction in any medium, provided the original work is properly cited.

Nearly 400 groundwater samples were collected from different types of aquifers in the Pearl River Delta (PRD), and the concentrations of groundwater arsenic (As) and other 22 hydrochemical parameters in different types of aquifers were then investigated. Results showed that groundwater As concentration was up to hundreds $\mu \mathrm{g} / \mathrm{L}$ in granular aquifers, while those in fissured aquifers and karst aquifers were only up to dozens and several $\mu \mathrm{g} / \mathrm{L}$, respectively. Correspondingly, about $9.4 \%$ and $2.3 \%$ samples with high concentrations $(>0.01 \mathrm{mg} / \mathrm{L})$ of As were in granular and fissured aquifers, respectively, but no samples with high concentration of As were in karst aquifers. The source and mobilization of groundwater As in granular aquifers are likely controlled by the following mechanism: organic matter in marine strata was mineralized and provided electrons for electron acceptors, resulting in the release of $\mathrm{NH}_{4}{ }^{+}$and $\mathrm{I}^{-}$and the reduction of $\mathrm{Fe} / \mathrm{Mn}$ and $\mathrm{NO}_{3}{ }^{-}$, and was accompanied with the mobilization of As from sediments into groundwater. By contrast, both natural processes including the competitive adsorption between As anions and $\mathrm{F}^{-} / \mathrm{PO}_{4}{ }^{3-} / \mathrm{HCO}_{3}{ }^{-}$and anthropogenic processes including industrialization were responsible for high concentrations of groundwater As in fissured aquifers.

\section{Introduction}

Arsenic (As) is discovered as one of the most common toxic elements in environments. Groundwater with high concentrations of As is a major environmental and public health problem on a global scale. According to the World Health Organization [1], the acceptable value of As in groundwater for drinking purpose is $10 \mu \mathrm{g} / \mathrm{l}$. High concentrations of As $(>10 \mu \mathrm{g} / \mathrm{L})$ in aquifers have been reported in many countries, such as Bangladesh [2], India [3], China [4], and the United States [5], and granular aquifers are paid the most attention due to the common occurrence of high levels of A.

Pearl River Delta (PRD) is one of the most important economic regions in China. On the one hand, urbanization has accelerated the contamination and deterioration of surface water quality in this region [6]. On the other hand, abundant groundwater is stored in aquifers and it is free of charge in this region. As a consequence, it is essential to investigate the distribution of As in aquifers of the whole PRD, in order to improve groundwater management in this region and increase the availability of groundwater for sustainable development of the PRD. Although a couple of studies had already reported the occurrence of high levels of As in granular aquifers of Xijiang river basin and Guangzhou area (both of them within the PRD) [7, 8], the distribution of As in karst aquifers and other areas within the PRD is little known.

The present study therefore aims to (1) investigate the concentrations of groundwater As in different types of aquifers in the whole PRD on a regional scale and (2) discuss the influence factors on the distribution of groundwater As in aquifers. Multivariate statistical techniques such as principal components analysis (PCA) have been used in this study, because PCA can not only help to understand the hydrochemical processes but also provide information about which factors are responsible for high levels of groundwater As in aquifers [7]. The results obtained from this study can be a useful reference on the groundwater management of this region. 


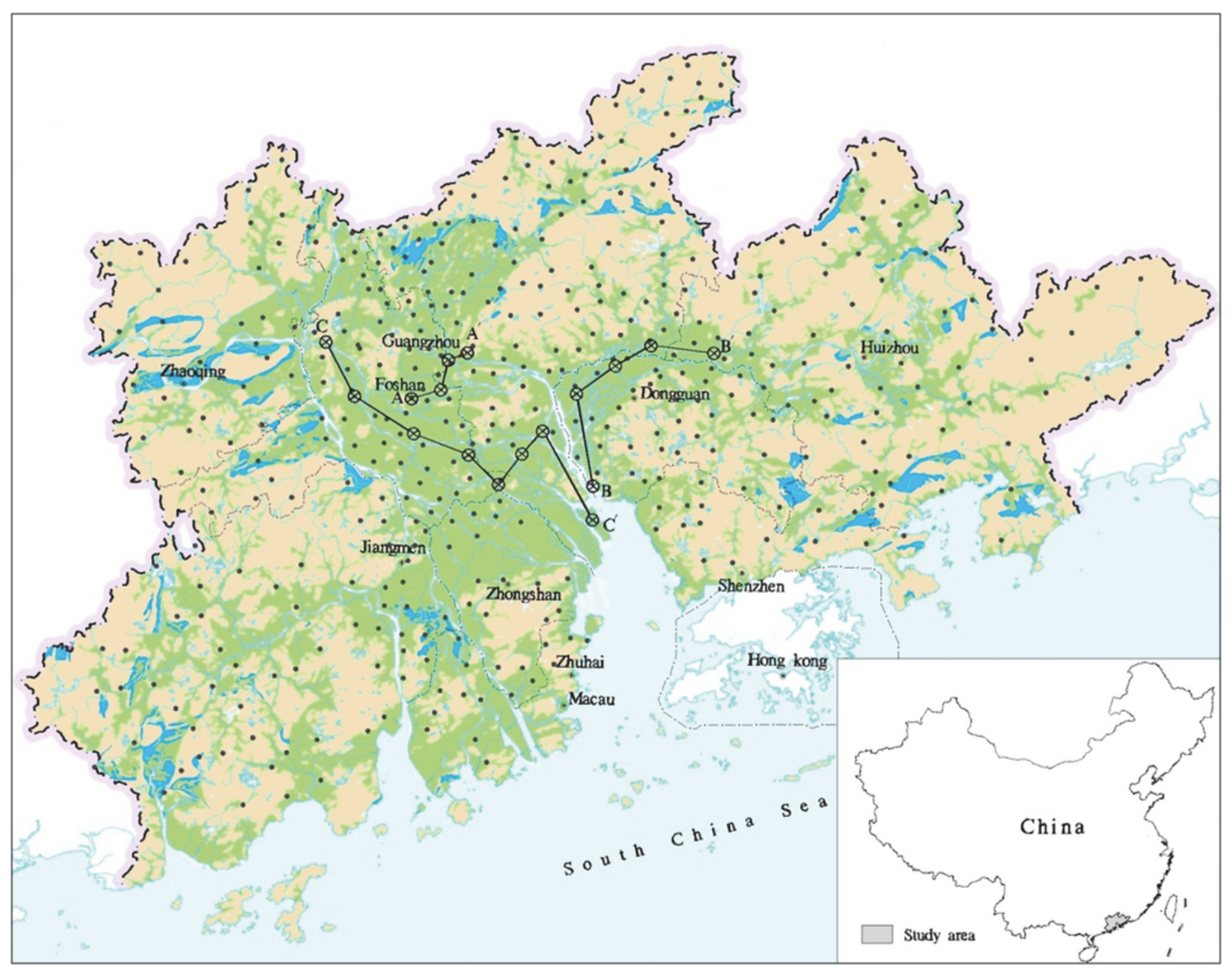

Granular aquifer

$-\otimes-$ Cross section

Fissured aquifer

- Sampling sites

Karst aquifer

FIGURE 1: Hydrogeological setting and sampling sites in the PRD.

\section{Study Area}

2.1. Geographical Conditions. The PRD $\left(111^{\circ} 59^{\prime}-115^{\circ} 25^{\prime} \mathrm{E}\right.$, $\left.21^{\circ} 17^{\prime}-23^{\circ} 55^{\prime} \mathrm{N}\right)$ is formed as a result of uplift of the Tibetan Plateau during the Tertiary and Quaternary Periods, locating in southern China (Figure 1). It is with the boundaries of hills in the east, west, and north and the South China Sea in the south, and the topography of PRD also inclines from the east, west, and north to the south. The total area is $41,698 \mathrm{~km}^{2}$, including Guangzhou, Shenzhen, Huizhou, Dongguan, Foshan, Zhaoqing, Zhongshan, Zhuhai, and Jiangmen city in district. The total population of the area is 43.15 million in 2005. The climate is typically subtropical monsoon, characterized by hot and wet summer and autumn and relatively cold and dry winter and spring. The annual average temperature is $21.9^{\circ} \mathrm{C}$, and the mean annual precipitation is $1800-2200 \mathrm{~mm}$. The PRD belongs to the drainage basin of Pearl River. East River, West River, and North River merge in the south of the area and compose the Pearl River and discharge into the South China Sea [9].
2.2. Geological and Hydrogeological Settings. The central and southern parts of the PRD are mostly covered by Quaternary sediments. Quaternary sediments consist of two terrestrial sequences and two marine sequences by the mode of overlaying each other [10]. The younger marine sequence is recorded at altitudes above $-20 \mathrm{~m}$, and the older marine sequence is recorded at altitudes between $-15 \mathrm{~m}$ and $-40 \mathrm{~m}$ (Figure 2). The younger terrestrial sequence can be sandy fluvial deposits or clayed silt weathered from the in situ materials during the last glacial period and becomes a local intermediate aquifer when it is sandy. The older terrestrial sequence is dominated by sand and gravel and becomes the basal aquifer. In many places, the older marine sequence and the younger terrestrial sequence are missing or decomposed into clay when the sea-level regressed during the last glacial period [10]. Groundwater is mainly recharged by vertical infiltration from precipitation and agricultural irrigation and during the floodtime and wet season by the lateral flow from rivers. The bedrocks include shale, sandstone, limestone, dolomite, granite, and gneiss ranging in age from Cambrian to Tertiary 

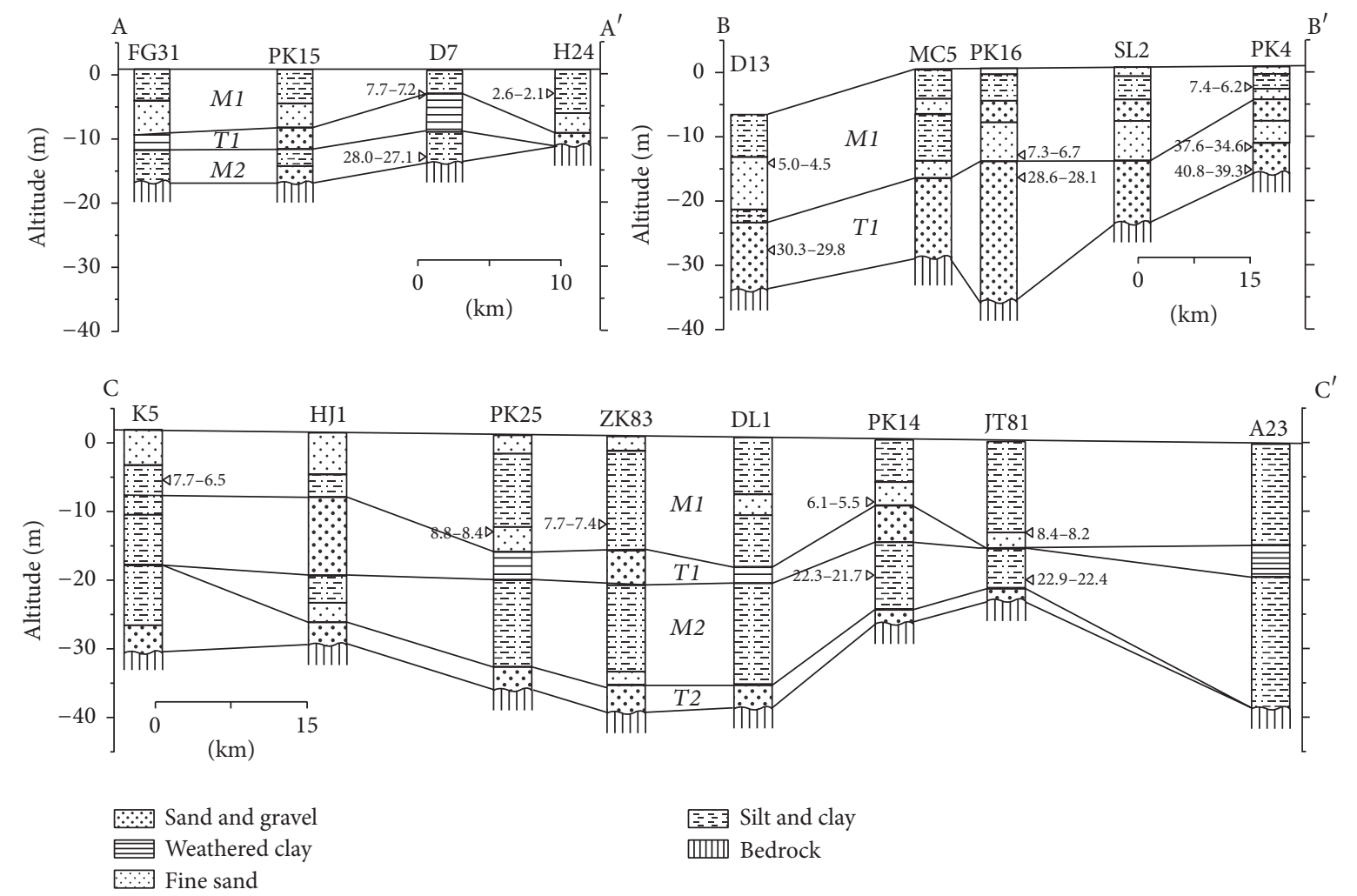

FIGURE 2: Cross sections in the PRD (from Zong et al. [10]).

and crop out around and within the PRD. Aquifers in this area are mainly associated with fractures and with springs yield up to hundreds $\mathrm{m}^{3} / \mathrm{d}$. Karst aquifers are less than $10 \%$ of the total area and around the PRD plain, and the groundwater yield can be as high as $1000 \mathrm{~m}^{3} / \mathrm{d}$. The general direction of regional groundwater flow in the aquifers of the PRD is northwest and northeast toward the coast [11].

\section{Materials and Methods}

3.1. Sample Collection. Groundwater samples were collected from 399 wells $(256,132$, and 11 wells in granular aquifers, fissured aquifers, and karst aquifers, respectively), and the sampling densities were 30-50 samples and 5-10 samples of $1000 \mathrm{~km}^{2}$ in plain and hilly areas, respectively. In order to ensure that the groundwater samples were representative of the in situ conditions, samples were collected after purging at least 2 borehole volumes. Two $250 \mathrm{~mL}$ polyethylene bottles were used to store filtered ( $1.2 \mu \mathrm{m}$ filter membrane) groundwater for trace elements and major ions analysis. One bottle was acidified with nitric acid to a $\mathrm{pH}$ less than 2 for trace elements determination. The other bottle for major ions analysis was unacidified. All samples were stored at $4^{\circ} \mathrm{C}$ until laboratory procedures could be performed.

3.2. Analytical Techniques. Electrical conductivity (EC), pH, electrode potential (Eh), and dissolved oxygen (DO) were measured in situ using WTW Multi 340i/SET multiparameters instrument (Germany), which was previously calibrated. All analyses were carried out at the Groundwater Mineral
Water and Environmental Monitoring Center of the Institute of Hydrogeology and Environmental Geology, Chinese Academy of Geological Sciences. Metal ions and trace elements (K, $\mathrm{Na}, \mathrm{Ca}, \mathrm{Mg}, \mathrm{Fe}, \mathrm{Mn}, \mathrm{As}$, and $\mathrm{Al}$ ) were measured by inductively coupled plasma-mass spectrometry (ICPMS) (Agilent 7500ce ICP-MS, Tokyo, Japan). Total dissolved solids (TDS) and total hardness (TH) were measured by gravimetric and EDTA titration method, respectively. $\mathrm{HCO}_{3}{ }^{-}$ was measured by acid-base titration, and $\mathrm{NH}_{4}{ }^{+}$and other anions $\left(\mathrm{NO}_{3}{ }^{-}, \mathrm{SO}_{4}{ }^{2-}, \mathrm{Cl}^{-}, \mathrm{NO}_{2}{ }^{-}, \mathrm{F}^{-}, \mathrm{Br}^{-}, \mathrm{I}^{-}\right.$, and $\left.\mathrm{PO}_{4}{ }^{3-}\right)$ were carried out on ion chromatography (IC) (Shimadzu LC$10 \mathrm{ADvp}$, Japan). The relative errors were less than $\pm 6 \%$ for all analyzed parameters.

3.3. Principal Components Analysis (PCA). PCA was useful for data reduction [6,7]. In this study, PCA was used to reduce the parameters and extract the main influence factors which are responsible for high concentrations of As in groundwater. In the PCA, the rotation of principal components (PCs) was carried out using the varimax method. The SPSS ${ }^{\circledR}$ release 23.0 (SPSS Inc., Chicago, USA) was used to analyze the groundwater chemical data.

\section{Results and Discussion}

4.1. Hydrochemical Characteristics. The descriptive statistics for the parameters analyzed in the groundwater samples are summarized in Table 1. Groundwater $\mathrm{pH}$ was predominantly acidic to near neutral in the PRD and similar range of $\mathrm{pH}$ in different types of aquifers. EC value was in a wide range 


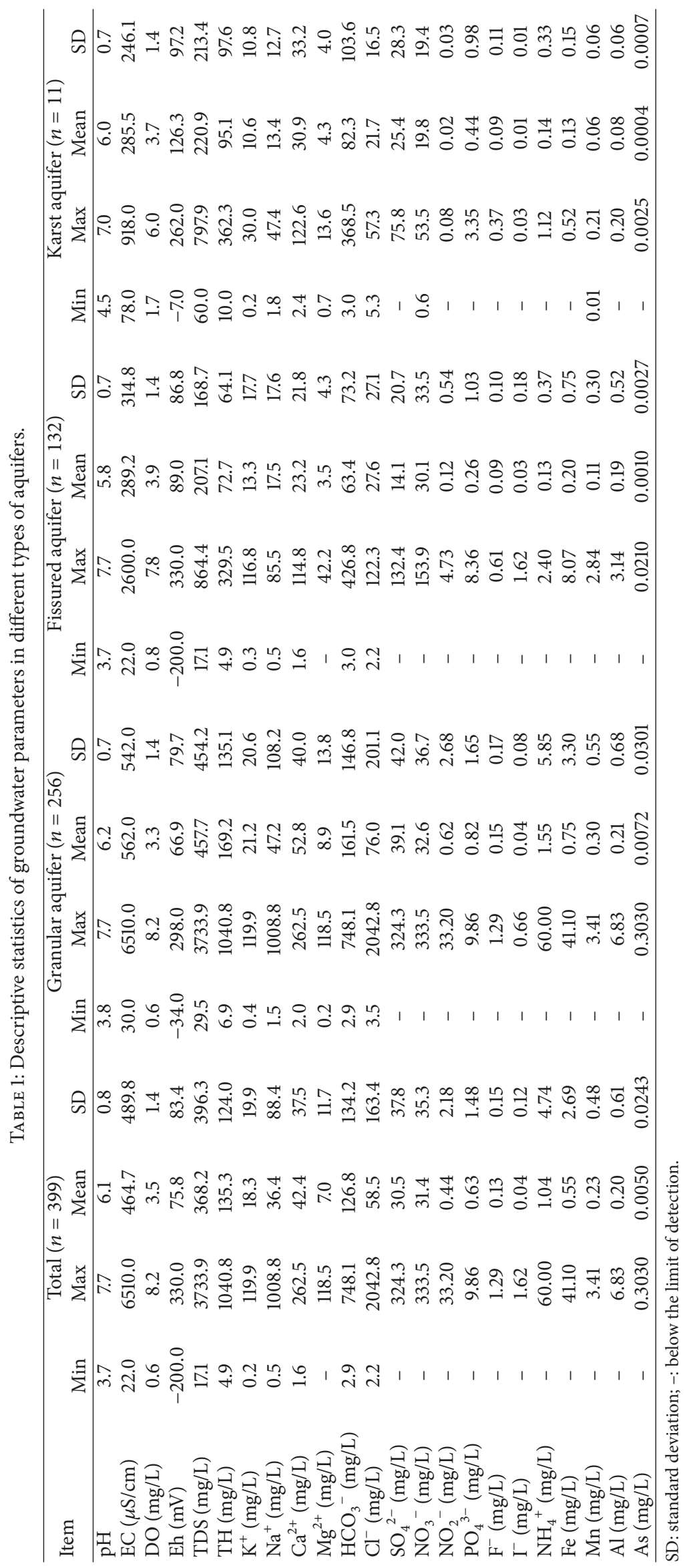




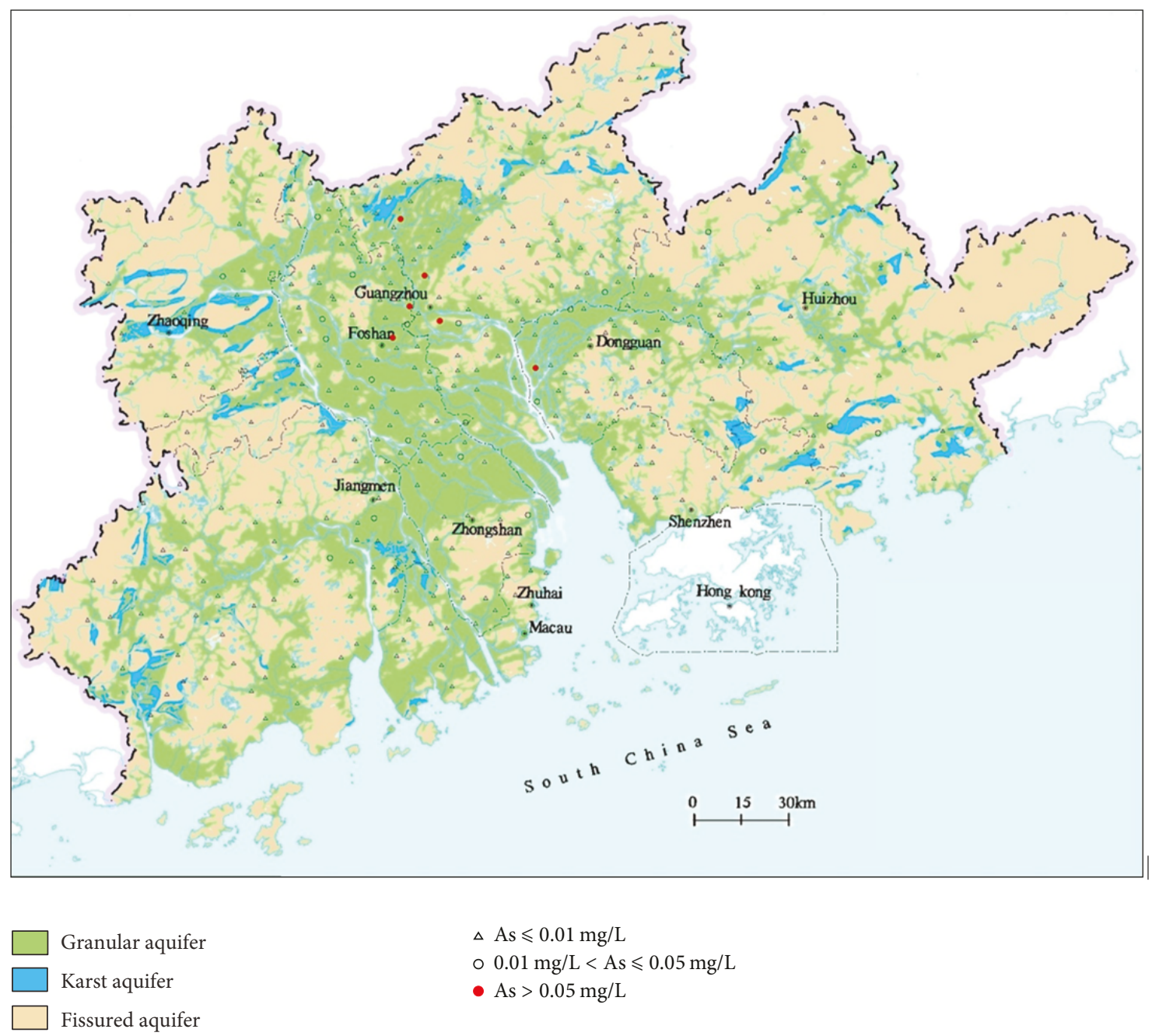

FIGURE 3: As concentrations in different types of aquifers in the PRD.

of $22 \mu \mathrm{S} / \mathrm{cm}$ to $6510 \mu \mathrm{S} / \mathrm{cm}$, and the mean and maximum values of EC in granular aquifers were far higher than that in fissured aquifers and karst aquifers. This may be attributed to the occurrence of sea water intrusion in granular aquifers, because sea water is characterized by high EC value and granular aquifers in the PRD are close to South China Sea while fissured and karst aquifers are relatively far from the sea [6]. DO and Eh values were also in a wide range. The mean value of Eh in karst aquifers was far higher than that in granular and fissured aquifers, indicating that the oxidability of karst aquifers in the PRD was commonly stronger than other two types of aquifers. TDS and TH values showed similar rules of the EC value in different types of aquifers in the PRD, which may also be ascribed to the occurrence of sea water intrusion in granular aquifers. The major cations of groundwater dominated with $\mathrm{Na}^{+}$and $\mathrm{Ca}^{2+}$, while the major anions dominated with $\mathrm{HCO}_{3}{ }^{-}$and $\mathrm{Cl}^{-}$in the whole PRD. It is worth mentioning that groundwater $\mathrm{NO}_{3}{ }^{-}$was also a major ion in aquifers in the whole PRD, not only in granular aquifers but also in fissured and karst aquifers, and the concentration of groundwater $\mathrm{NO}_{3}{ }^{-}$was up to hundreds $\mathrm{mg} / \mathrm{L}$ in both granular aquifers and fissured aquifers. Correspondingly, the concentrations of other two nitrogen compounds in aquifers of the PRD were up to dozens $\mathrm{mg} / \mathrm{L}$, and the mean and maximum values of both groundwater $\mathrm{NO}_{3}{ }^{-}$and $\mathrm{NH}_{4}{ }^{+}$in granular aquifers were far higher than that in fissured and karst aquifers. No distinct difference of concentrations of groundwater $\mathrm{PO}_{4}{ }^{3-}$ and $\mathrm{F}^{-}$in different types of aquifers in the PRD was found. The concentration of groundwater $\mathrm{I}^{-}$ in granular and fissured aquifers was commonly higher than that in karst aquifers. The concentration of groundwater $\mathrm{Fe}$ in different types of aquifers showed a significant difference with the highest mean value in granular aquifers and lowest mean value in karst aquifers. The concentrations of groundwater $\mathrm{Mn}$ and $\mathrm{Al}$ in granular and fissured aquifers were generally higher than those in karst aquifers. The concentration of groundwater As in different types of aquifers also showed a significant difference. The concentration of groundwater As in granular aquifers was up to hundreds $\mu \mathrm{g} / \mathrm{L}$, while those in fissured aquifers and karst aquifers were only up to dozens and several $\mu \mathrm{g} / \mathrm{L}$, respectively (Table 1 ).

4.2. Spatial Distribution of As in Aquifers of the PRD. As it can be seen from Figure 3, the highest proportion of groundwater 
TABLE 2: Principal component (PC) loadings for groundwater samples in granular aquifers.

\begin{tabular}{|c|c|c|c|c|c|c|c|}
\hline Item & PC1 & PC2 & PC3 & PC4 & PC5 & PC6 & PC7 \\
\hline $\mathrm{pH}$ & 0.105 & 0.755 & 0.163 & 0.174 & 0.025 & -0.011 & -0.043 \\
\hline EC & 0.766 & 0.432 & 0.196 & 0.102 & 0.386 & -0.053 & 0.003 \\
\hline DO & -0.274 & -0.206 & -0.163 & -0.134 & -0.045 & 0.500 & -0.312 \\
\hline $\mathrm{Eh}$ & -0.015 & -0.248 & -0.051 & -0.055 & 0.069 & 0.707 & 0.219 \\
\hline $\mathrm{K}^{+}$ & 0.314 & 0.286 & 0.046 & -0.044 & 0.804 & -0.035 & 0.038 \\
\hline $\mathrm{Na}^{+}$ & 0.942 & 0.151 & 0.065 & 0.053 & 0.107 & -0.085 & 0.027 \\
\hline $\mathrm{Ca}^{2+}$ & 0.324 & 0.753 & 0.239 & 0.158 & 0.314 & -0.233 & -0.043 \\
\hline $\mathrm{Mg}^{2+}$ & 0.812 & 0.277 & 0.079 & 0.067 & 0.100 & 0.174 & -0.059 \\
\hline $\mathrm{NH}_{4}^{+}$ & 0.240 & 0.186 & 0.571 & 0.519 & -0.113 & 0.260 & -0.072 \\
\hline $\mathrm{Fe}$ & 0.125 & 0.060 & 0.244 & 0.672 & -0.141 & -0.324 & 0.123 \\
\hline $\mathrm{HCO}_{3}{ }^{-}$ & 0.363 & 0.712 & 0.431 & 0.272 & -0.026 & -0.109 & -0.048 \\
\hline $\mathrm{Cl}^{-}$ & 0.945 & 0.092 & 0.010 & 0.039 & 0.178 & -0.057 & 0.030 \\
\hline $\mathrm{SO}_{4}{ }^{2-}$ & 0.399 & 0.541 & -0.131 & 0.064 & 0.420 & -0.168 & 0.026 \\
\hline $\mathrm{F}^{-}$ & 0.135 & 0.717 & -0.098 & -0.100 & -0.223 & -0.031 & 0.203 \\
\hline $\mathrm{NO}_{3}^{-}$ & 0.236 & -0.174 & -0.072 & -0.157 & 0.814 & 0.068 & -0.048 \\
\hline TDS & 0.675 & 0.530 & 0.294 & 0.138 & 0.350 & -0.129 & -0.026 \\
\hline $\mathrm{TH}$ & 0.535 & 0.692 & 0.217 & 0.148 & 0.283 & -0.125 & -0.054 \\
\hline $\mathrm{I}^{-}$ & -0.021 & 0.136 & 0.361 & 0.684 & 0.088 & 0.039 & 0.186 \\
\hline $\mathrm{PO}_{4}{ }^{3-}$ & 0.048 & 0.203 & 0.900 & 0.064 & 0.031 & 0.016 & 0.023 \\
\hline $\mathrm{Al}$ & -0.034 & 0.019 & -0.011 & 0.047 & -0.018 & 0.096 & 0.905 \\
\hline $\mathrm{Mn}$ & 0.058 & 0.075 & -0.127 & 0.851 & -0.070 & 0.044 & -0.116 \\
\hline $\mathrm{NO}_{2}^{-}$ & 0.252 & 0.338 & 0.218 & 0.376 & -0.156 & 0.541 & 0.063 \\
\hline As & 0.101 & 0.022 & 0.890 & 0.116 & -0.021 & -0.147 & -0.004 \\
\hline Eigenvalue & 4.6 & 3.9 & 2.7 & 2.3 & 2.1 & 1.4 & 1.1 \\
\hline Explained variance (\%) & 19.9 & 17.1 & 11.7 & 10.1 & 9.2 & 6.2 & 4.8 \\
\hline Cumulative $\%$ of variance & 19.9 & 37.0 & 48.8 & 58.9 & 68.1 & 74.3 & 79.1 \\
\hline
\end{tabular}

samples with high concentrations of As was in Foshan city, and it was $16.7 \%$, which was followed by Zhongshan (10.5\%), Dongguan (7.3\%), Shenzhen (6.7\%), Guangzhou (6.6\%), Huizhou (4.8\%), Zhaoqing (3.6\%), Jiangmen $(3.3 \%)$, and Zhuhai city $(0 \%)$ in district. In granular aquifers, the occurrence of groundwater with high concentrations of As in West River and North River Delta plain was more frequent than that in East River Delta plain. Correspondingly, only one sample with extremely high concentrations of As $(>0.05 \mathrm{mg} / \mathrm{L})$ was in the East River Delta plain, while others were in the West River and North River Delta plain. According to the guideline value of As by the WHO (2011), approximately $6.8 \%$ and $9.4 \%$ samples exceeded the guideline value in aquifers of the whole PRD and granular aquifers, while only about $2.3 \%$ and no samples exceeded the guideline value in fissured aquifers and karst aquifers, respectively (Figure 3). Therefore, the following discussion will focus on the factors which are responsible for high concentrations of As in granular and fissured aquifers.

4.3. As in Granular Aquifers. According to our in situ investigation, groundwater samples with high As concentrations in granular aquifers were commonly of no significant potential source of As which is caused by human activities [9]. Thus, we concluded that the occurrence of high concentrations of
As in granular aquifers was mainly ascribed to the geologic origin. PCA was used to reduce the parameters and evaluate the relationships between As and other hydrochemical parameters [7]. In granular aquifers, the rotation of PCs was carried out using the varimax method, and seven PCs were extracted from the PCA method. The PC1, PC2, PC3, PC4, PC5, PC6, and PC7 explained 19.9\%, 17.1\%, 11.7\%, 10.1\%, 9.2\%, $6.2 \%$, and $4.8 \%$ of the total variance, respectively, and the cumulative variance by the seven PCs was 79.1\% (Table 2). PC3, consisting of $\mathrm{NH}_{4}{ }^{+}, \mathrm{PO}_{4}{ }^{3-}$, and As, indicates that the occurrence of groundwater As in granular aquifers was closely related to $\mathrm{NH}_{4}{ }^{+}$and $\mathrm{PO}_{4}{ }^{3-}$. It is known that high concentration of groundwater $\mathrm{NH}_{4}{ }^{+}$in granular aquifers was mainly originated from the overlying Holocene-Pleistocene aquitard and entered the granular aquifers by groundwater transport and diffusion, because much organic nitrogen remained in the aquitard available for conversion to $\mathrm{NH}_{4}^{+}$ $[12,13]$. It is also known that the microbially mediated mobilization of As with the organic nutrient (including organic nitrogen) as an electron donor is strongly associated with the exchangeable As [14]. Therefore, $\mathrm{NH}_{4}{ }^{+}$and As in the same PC indicate that $\mathrm{NH}_{4}{ }^{+}$and As have the same origin in granular aquifers, because organic nitrogen in the aquitard was converted to $\mathrm{NH}_{4}{ }^{+}$and accompanied by the mobilization of As in the aquitard, and finally As entered the granular 
aquifers by groundwater transport. To our knowledge, $\mathrm{PO}_{4}{ }^{3-}$ and As in water have competitive relationship [15], which should be responsible for $\mathrm{PO}_{4}{ }^{3-}$ and $\mathrm{As}$ in the same $\mathrm{PC}$ in granular aquifers.

After the PCs were reduced from seven PCs to two PCs, we found groundwater As in granular aquifers was not only closely related to $\mathrm{NH}_{4}{ }^{+}$and $\mathrm{PO}_{4}{ }^{3-}$ but also related to $\mathrm{Fe}$, $\mathrm{I}^{-}, \mathrm{NO}_{2}{ }^{-}$, and $\mathrm{Mn}$ (Figure 4). The good relationship of As and $\mathrm{Fe} / \mathrm{Mn}$ indicates that As would be associated with $\mathrm{Fe} / \mathrm{Mn}$ oxide minerals in the granular aquifers, which generally have strong affinity for both $\mathrm{As}(\mathrm{III})$ and $\mathrm{As}(\mathrm{V})[16,17]$. This is confirmed by the aging experiments and the sequential extraction method [18]. In addition, good correspondence between $\mathrm{As}$ and $\mathrm{Fe} / \mathrm{Mn}$ has been observed in the Quaternary sediments of the PRD [8] which also supports the above conclusion. The good relationship between As and $\mathrm{NO}_{2}{ }^{-}$ indicates that the mobilization of As in granular aquifers would be accompanied by the reduction of $\mathrm{NO}_{3}{ }^{-}$to $\mathrm{NO}_{2}{ }^{-}$. It is known that rich dissolved organic carbon (DOC) occurs in the Quaternary sediments of the PRD and is the trigger for the formation of reducing condition [12]. High concentrations of DOC provide electrons for electron acceptors, which commonly leads to the reduction of $\mathrm{NO}_{3}{ }^{-}$. This is further confirmed by the hydrochemical data in granular aquifers of the PRD. Because high concentrations $(>0.01 \mathrm{mg} / \mathrm{L})$ of As in granular aquifers of the PRD were accompanied by the relatively low concentrations of $\mathrm{NO}_{3}{ }^{-}$(mean value of $9.9 \mathrm{mg} / \mathrm{L}$ ) and high levels of $\mathrm{NO}_{2}{ }^{-}$(mean value of $0.97 \mathrm{mg} / \mathrm{L}$ ), by contrast, low concentrations of As in granular aquifers were accompanied by the relatively high concentrations of $\mathrm{NO}_{3}{ }^{-}$(mean value of $34.9 \mathrm{mg} / \mathrm{L}$ ) and low levels of $\mathrm{NO}_{2}{ }^{-}$ (mean value of $0.58 \mathrm{mg} / \mathrm{L}$ ). $\mathrm{I}^{-}$and As have the same origin in granular aquifers which may be responsible for the good correspondence between As and $\mathrm{I}^{-}$in granular aquifers of the PRD because $\mathrm{I}^{-}$is generally derived from I-rich organic matter in marine strata [19], and two of the Quaternary sediments in the PRD are marine strata with rich organic matter $[10,12]$. In addition, as mentioned above, mineralization of sedimentary organic matter is contributed to the occurrence of high concentrations of As in granular aquifers of the PRD [8].

To sum up, the main mechanism controlling the source and mobilization of groundwater As in granular aquifers of the PRD may be as follows: organic matter in marine strata was mineralized and provided electrons for electron acceptors, resulting in the release of $\mathrm{NH}_{4}{ }^{+}$and $\mathrm{I}^{-}$and the reduction of $\mathrm{Fe} / \mathrm{Mn}$ and $\mathrm{NO}_{3}{ }^{-}$, and was accompanied with the mobilization of As from sediments into groundwater.

4.4. As in Fissured Aquifers. On the one hand, groundwater samples with high concentrations of As in fissured aquifers were located at the construction land, where many factories run and generally discharge their wastewater without treatment according to our investigation [9]. On the other hand, the sediments above the fissured aquifers were commonly characterized by coarse particles, leading to the weak ability for the prevention of contaminants from ground surface into aquifers. Therefore, anthropogenic source should be one of the factors for high concentrations of groundwater As in

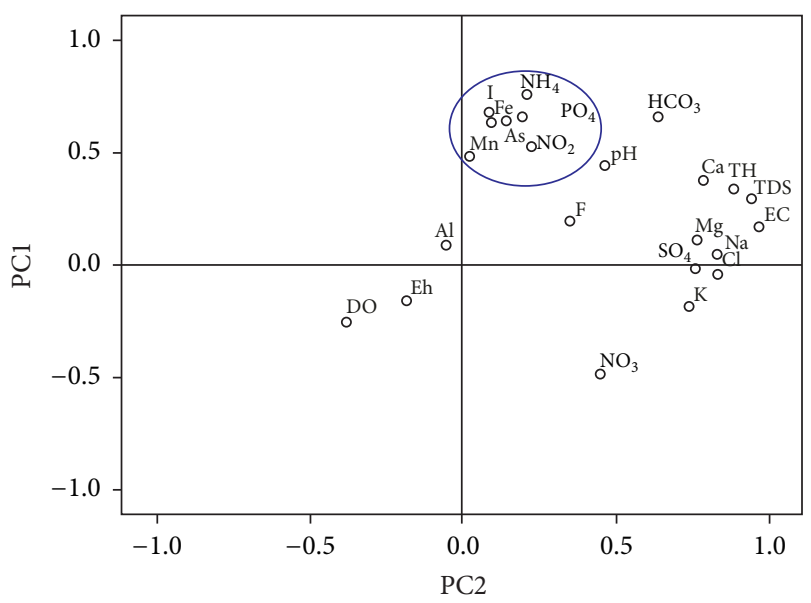

FIgURE 4: The relationship of hydrochemical parameters in two main PCs in granular aquifers.

fissured aquifers of the PRD. Six PCs were extracted from the groundwater samples in fissured aquifers by the PCA method. The PC1, PC2, PC3, PC4, PC5, and PC6 explained $36.3 \%, 12.7 \%, 8.5 \%, 8.1 \%, 6.3 \%$, and $5.3 \%$ of the total variance, respectively, and the cumulative variance by the six PCs was 77.1\% (Table 3). $\mathrm{PC} 2$, consisting of $\mathrm{HCO}_{3}{ }^{-}, \mathrm{F}^{-}, \mathrm{PO}_{4}{ }^{3-}$, and As, indicates that the occurrence of groundwater As in fissured aquifers was closely related to $\mathrm{HCO}_{3}{ }^{-}, \mathrm{F}^{-}$, and $\mathrm{PO}_{4}{ }^{3-}$. On the one hand, to our knowledge, the presence of $\mathrm{HCO}_{3}{ }^{-}$ would alter the surface charge properties of $\mathrm{Fe}$ oxides via inner-sphere monodentate mononuclear surface species, and the $\mathrm{HCO}_{3}{ }^{-}$readily competes with As anions for adsorption sites on the Fe oxides at concentration $>61 \mathrm{mg} / \mathrm{L}$, which has been evidenced by some experiments [4]. Correspondingly, the mean concentration of $\mathrm{HCO}_{3}{ }^{-}$in fissured aquifers was more than $61 \mathrm{mg} / \mathrm{L}$ (Table 1). On the other hand, it is known that carbonate rocks commonly contain higher content of As than other rocks such as igneous rocks, indicating that the dissolution of carbonate rocks would accompany the release of As and $\mathrm{HCO}_{3}{ }^{-}$[7]. These two mechanisms may be responsible for the good relationship between As and $\mathrm{HCO}_{3}{ }^{-}$ in fissured aquifers. To our knowledge, the competition for adsorption sites of the minerals between $\mathrm{F}^{-} / \mathrm{PO}_{4}{ }^{3-}$ and $\mathrm{As}$ anions occurs $[15,20,21]$, which may be responsible for the good correspondence between $\mathrm{F}^{-} / \mathrm{PO}_{4}{ }^{3-}$ and As in fissured aquifers. In conclusion, high concentrations of groundwater As in fissured aquifers of the PRD are attributed to the coupling effects of anthropogenic and natural processes such as anion exchange of $\mathrm{F}^{-} / \mathrm{PO}_{4}{ }^{3-}$ and As anions.

\section{Conclusions}

The concentration of groundwater As in different types of aquifers in the PRD showed a significant difference. In granular aquifers, groundwater As concentration was up to hundreds $\mu \mathrm{g} / \mathrm{L}$, while those in fissured aquifers and karst aquifers were only up to dozens $\mu \mathrm{g} / \mathrm{L}$ and several $\mu \mathrm{g} / \mathrm{L}$, respectively. Correspondingly, about $9.4 \%$ and $2.3 \%$ samples with high concentration of As were in granular and fissured 
TABLE 3: Principal component loadings for groundwater samples in fissured aquifers.

\begin{tabular}{|c|c|c|c|c|c|c|}
\hline Item & $\mathrm{PCl}$ & PC2 & PC3 & $\mathrm{PC} 4$ & PC5 & PC6 \\
\hline $\mathrm{pH}$ & 0.237 & 0.237 & 0.754 & -0.108 & -0.211 & -0.120 \\
\hline EC & 0.944 & 0.138 & 0.044 & 0.079 & -0.025 & 0.040 \\
\hline DO & -0.399 & -0.140 & -0.033 & -0.350 & -0.505 & 0.018 \\
\hline $\mathrm{Eh}$ & 0.037 & -0.354 & -0.531 & -0.056 & -0.156 & -0.242 \\
\hline $\mathrm{K}^{+}$ & 0.876 & 0.011 & 0.055 & -0.051 & -0.171 & -0.077 \\
\hline $\mathrm{Na}^{+}$ & 0.846 & 0.166 & -0.072 & 0.197 & 0.146 & 0.220 \\
\hline $\mathrm{Ca}^{2+}$ & 0.788 & 0.474 & 0.250 & 0.063 & 0.067 & 0.067 \\
\hline $\mathrm{Mg}^{2+}$ & 0.758 & 0.130 & -0.049 & 0.103 & 0.163 & -0.021 \\
\hline $\mathrm{NH}_{4}^{+}$ & -0.010 & 0.115 & 0.053 & 0.902 & -0.093 & 0.162 \\
\hline $\mathrm{Fe}$ & -0.146 & -0.076 & 0.024 & -0.054 & 0.831 & 0.104 \\
\hline $\mathrm{HCO}_{3}{ }^{-}$ & 0.563 & 0.619 & 0.357 & 0.161 & 0.214 & -0.043 \\
\hline $\mathrm{Cl}^{-}$ & 0.893 & 0.003 & -0.132 & 0.118 & 0.065 & 0.240 \\
\hline $\mathrm{SO}_{4}{ }^{2-}$ & 0.832 & 0.076 & 0.212 & 0.036 & -0.153 & -0.200 \\
\hline $\mathrm{F}^{-}$ & 0.046 & 0.434 & 0.225 & -0.298 & -0.019 & 0.006 \\
\hline $\mathrm{NO}_{3}^{-}$ & 0.818 & -0.146 & -0.243 & -0.097 & -0.145 & 0.274 \\
\hline TDS & 0.930 & 0.300 & 0.127 & 0.076 & 0.073 & 0.073 \\
\hline $\mathrm{TH}$ & 0.840 & 0.433 & 0.202 & 0.076 & 0.093 & 0.053 \\
\hline $\mathrm{I}^{-}$ & 0.292 & 0.232 & 0.050 & 0.572 & 0.361 & -0.130 \\
\hline $\mathrm{PO}_{4}{ }^{3-}$ & 0.276 & 0.865 & -0.003 & 0.060 & 0.043 & -0.119 \\
\hline $\mathrm{Al}$ & 0.077 & 0.074 & -0.817 & -0.075 & -0.090 & -0.021 \\
\hline $\mathrm{Mn}$ & 0.499 & -0.289 & -0.065 & 0.433 & 0.234 & -0.291 \\
\hline $\mathrm{NO}_{2}^{-}$ & 0.250 & -0.058 & 0.051 & 0.065 & 0.092 & 0.865 \\
\hline As & 0.085 & 0.797 & 0.044 & 0.402 & -0.147 & 0.050 \\
\hline Eigenvalue & 8.3 & 2.9 & 2.0 & 1.9 & 1.4 & 1.2 \\
\hline Explained variance (\%) & 36.3 & 12.7 & 8.5 & 8.1 & 6.3 & 5.3 \\
\hline Cumulative $\%$ of variance & 36.3 & 48.9 & 57.5 & 65.6 & 71.8 & 77.1 \\
\hline
\end{tabular}

aquifers, respectively, but no samples with high concentration of As was in karst aquifers. In granular aquifers, the occurrence of groundwater with high concentrations of As in West River and North River Delta plain was more frequent than that in East River Delta plain.

In granular aquifers, groundwater As was closely related to $\mathrm{NH}_{4}{ }^{+}, \mathrm{PO}_{4}{ }^{3-}, \mathrm{Fe}, \mathrm{I}^{-}, \mathrm{NO}_{2}{ }^{-}$, and $\mathrm{Mn}$. The source and mobilization of groundwater As in granular aquifers are likely to be controlled by the following mechanism: organic matter in marine strata was mineralized and provided electrons for electron acceptors, resulting in the release of $\mathrm{NH}_{4}{ }^{+}$and $\mathrm{I}^{-}$and the reduction of $\mathrm{Fe} / \mathrm{Mn}$ and $\mathrm{NO}_{3}{ }^{-}$, and was accompanied with the mobilization of As from sediments into groundwater. By contrast, not only were the natural processes such as the competitive adsorption between $\mathrm{As}$ anions and $\mathrm{F}^{-} / \mathrm{PO}_{4}{ }^{3-} / \mathrm{HCO}_{3}{ }^{-}$an important factor, but the anthropogenic processes were also responsible for high concentrations of groundwater As in fissured aquifers.

\section{Conflicts of Interest}

The authors declare that they have no conflicts of interest.

\section{Acknowledgments}

This research was supported by the Fundamental Research Funds for Central Public Welfare Research Institutes, CAGS (SK201611), China Geological Survey project (DD20160309, DD20179609, and DD20160308), and the National Natural Science Foundation of China (41472264, 41772334).

\section{References}

[1] World Health Organization (WHO), Guidelines for DrinkingWater Quality, Geneva, Switzerland, 4th edition edition, 2011.

[2] A. H. M. Selim Reza, J.-S. Jean, H.-J. Yang et al., "Occurrence of arsenic in core sediments and groundwater in the ChapaiNawabganj District, northwestern Bangladesh," Water Research, vol. 44, no. 6, pp. 2021-2037, 2010.

[3] S. Kar, J. P. Maity, J.-S. Jean et al., "Arsenic-enriched aquifers: Occurrences and mobilization of arsenic in groundwater of Ganges Delta Plain, Barasat, West Bengal, India," Applied Geochemistry, vol. 25, no. 12, pp. 1805-1814, 2010.

[4] H. Guo, D. Wen, Z. Liu, Y. Jia, and Q. Guo, "A review of high arsenic groundwater in Mainland and Taiwan, China: distribution, characteristics and geochemical processes," Applied Geochemistry, vol. 41, pp. 196-217, 2014. 
[5] L. M. Camacho, M. Gutiérrez, M. T. Alarcón-Herrera, M. D. L. Villalba, and S. Deng, "Occurrence and treatment of arsenic in groundwater and soil in northern Mexico and southwestern USA," Chemosphere, vol. 83, no. 3, pp. 211-225, 2011.

[6] G. Huang, J. Sun, Y. Zhang, Z. Chen, and F. Liu, "Impact of anthropogenic and natural processes on the evolution of groundwater chemistry in a rapidly urbanized coastal area, South China," Science of the Total Environment, vol. 463-464, pp. 209-221, 2013.

[7] G. Huang, Z. Chen, F. Liu, J. Sun, and J. Wang, "Impact of human activity and natural processes on groundwater arsenic in an urbanized area (South China) using multivariate statistical techniques," Environmental Science and Pollution Research, vol. 21, no. 22, pp. 13043-13054, 2014.

[8] Y. Wang, J. J. Jiao, and J. A. Cherry, "Occurrence and geochemical behavior of arsenic in a coastal aquifer-aquitard system of the Pearl River Delta, China," Science of the Total Environment, vol. 427-428, pp. 286-297, 2012.

[9] J. Sun, J. Jing, G. Huang, J. Liu, X. Chen, and Y. Zhang, "Report on the investigation and assessment of groundwater contamination in the Pearl River delta area," in The Institute of Hydrogeology and Environmental Geology, Chinese Academy of Geological Sciences, Shijiazhuang, China, 2009.

[10] Y. Zong, W. W.-S. Yim, F. Yu, and G. Huang, "Late Quaternary environmental changes in the Pearl River mouth region, China," Quaternary International, vol. 206, no. 1-2, pp. 35-45, 2009.

[11] Guangdong Hydrogeological Second Team (GHST), "Regional hydrogeological survey report," Guangdong Hydrogeological Second Team, Guangzhou, China, 1981 (Chinese).

[12] J. J. Jiao, Y. Wang, J. A. Cherry et al., "Abnormally high ammonium of natural origin in a coastal aquifer-aquitard system in the pearl river delta, China," Environmental Science \& Technology, vol. 44, no. 19, pp. 7470-7475, 2010.

[13] G. Huang, C. Liu, J. Sun, M. Zhang, J. Jing, and L. Li, "A regional scale investigation on factors controlling the groundwater chemistry of various aquifers in a rapidly urbanized area: A case study of the Pearl River Delta," Science of the Total Environment, vol. 625 , pp. 510-518, 2018.

[14] H. Guo, X. Tang, S. Yang, and Z. Shen, "Effect of indigenous bacteria on geochemical behavior of arsenic in aquifer sediments from the Hetao Basin, Inner Mongolia: Evidence from sediment incubations," Applied Geochemistry, vol. 23, no. 12, pp. 32673277, 2008.

[15] G. Huang, Z. Chen, J. Wang, J. Sun, J. Liu, and Y. Zhang, "Adsorption of arsenite onto a soil irrigated by sewage," Journal of Geochemical Exploration, vol. 132, pp. 164-172, 2013.

[16] G. Huang, Z. Chen, J. Sun, F. Liu, J. Wang, and Y. Zhang, "Effect of sample pretreatment on the fractionation of arsenic in anoxic soils," Environmental Science and Pollution Research, vol. 22, no. 11, pp. 8367-8374, 2015.

[17] G. Huang, Z. Chen, Y. Zhang, F. Liu, J. Wang, and Q. Hou, "Changes of arsenic fractionation and bioaccessibility in wastewater-irrigated soils as a function of aging: Influence of redox condition and arsenic load," Geoderma, vol. 280, pp. 1-7, 2016.

[18] G. Huang, Z. Chen, J. Wang, Q. Hou, and Y. Zhang, "Impact of temperature on the aging mechanisms of arsenic in soils: fractionation and bioaccessibility," Environmental Science and Pollution Research, vol. 23, no. 5, pp. 4594-4601, 2016.

[19] D. Wen, F. Zhang, E. Zhang, C. Wang, S. Han, and Y. Zheng, "Arsenic, fluoride and iodine in groundwater of China," Journal of Geochemical Exploration, vol. 135, pp. 1-21, 2013.
[20] R. P. Liu, W. X. Gong, H. C. Lan, T. M. Yang, H. J. Liu, and J. H. Qu, "Simultaneous removal of arsenate and fluoride by iron and aluminum binary oxide: competitive adsorption effects," Separation and Purification Technology, vol. 92, pp. 100-105, 2012.

[21] Q. Yang, H. B. Jung, R. G. Marvinney, C. W. Culbertson, and Y. Zheng, "Can arsenic occurrence rates in bedrock aquifers be predicted?" Environmental Science \& Technology, vol. 46, no. 4, pp. 2080-2087, 2012. 

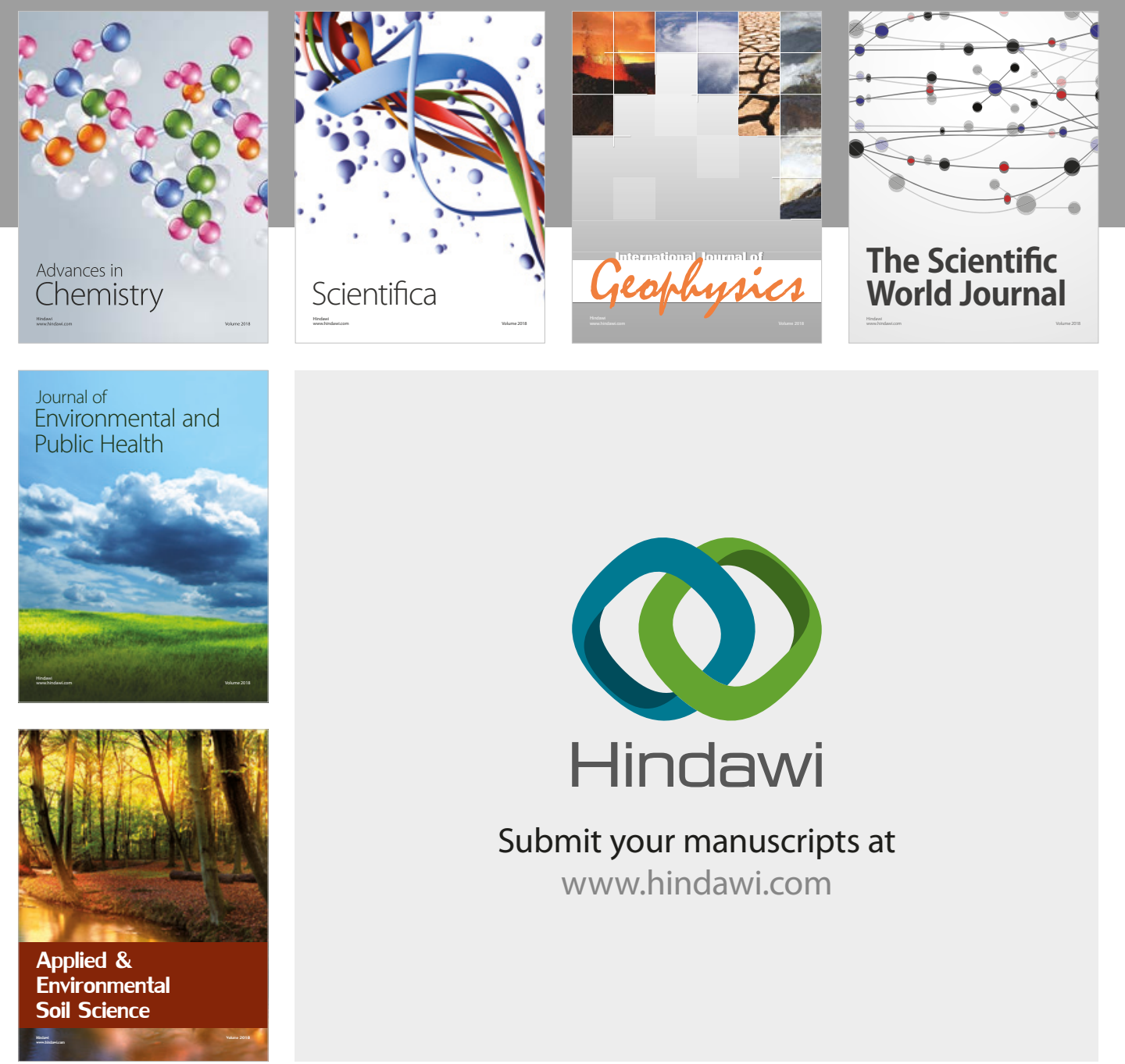

The Scientific

\section{World Journal}
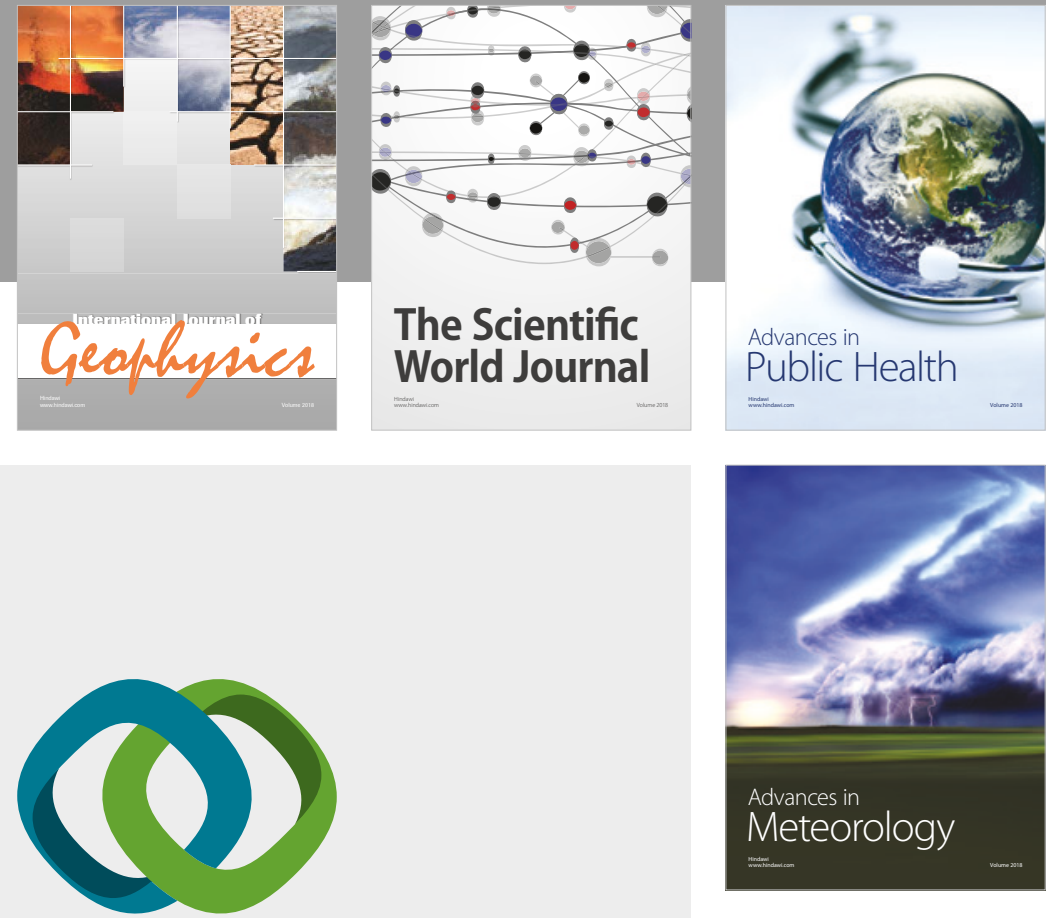

Advan

Public Health

\section{Hindawi}

Submit your manuscripts at

www.hindawi.com
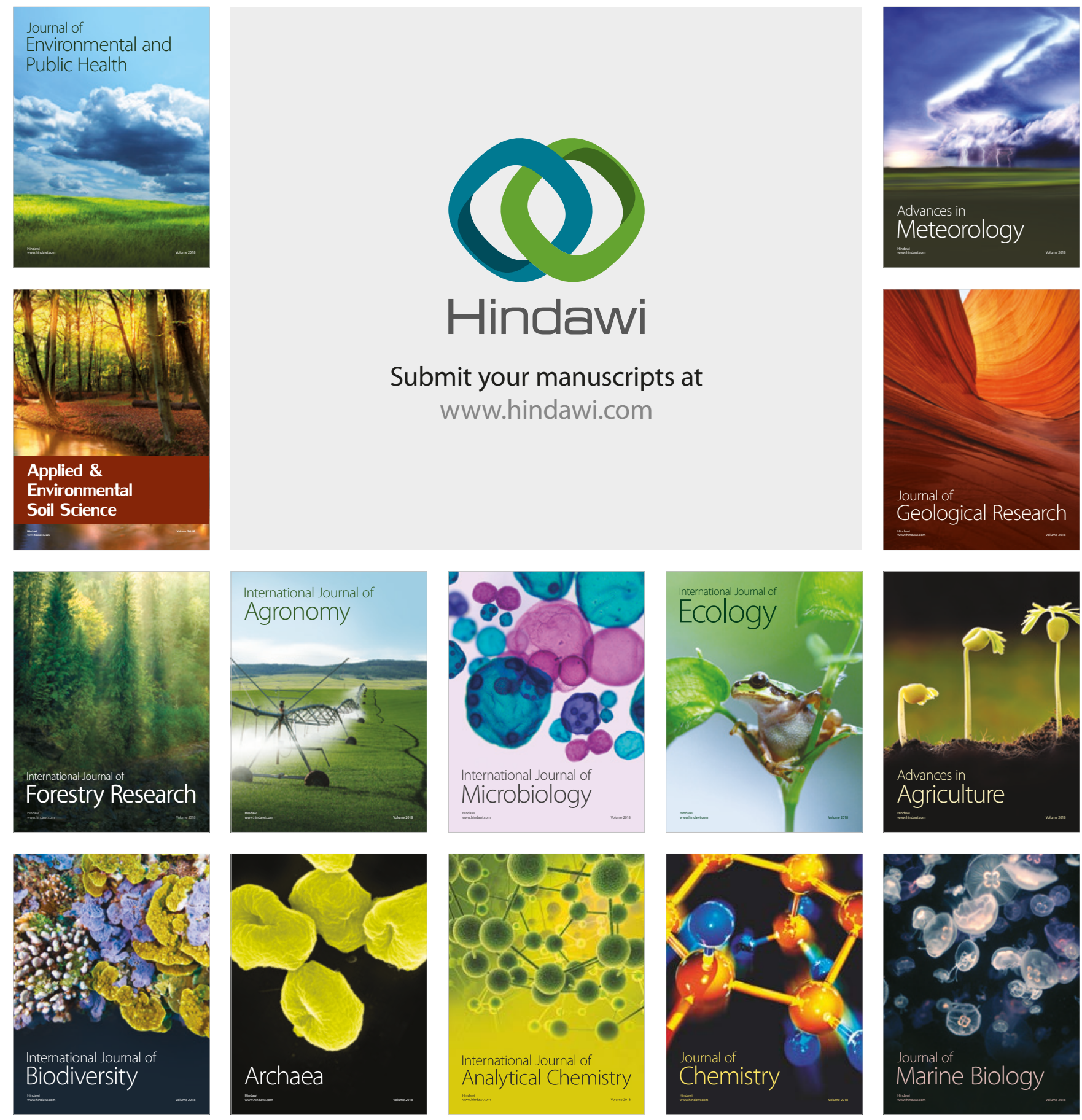